\title{
On the Growth in Normativity in International Relations
}

\author{
Jan-Erik Lane ${ }^{1}$ \\ ${ }^{1}$ Department of Political Science, University of Freiburg im Breisgau, Freiburg, Germany \\ Correspondence: Jan-Erik Lane, Department of Political Science, University of Freiburg im Breisgau, Freiburg, \\ Germany. Tel: 49-761-203-9372. E-mail: janeriklane34@googlemail.com
}

Received: December 24, 2012 Accepted: January 9, 2013 Online Published: February 26, 2013

doi:10.5539/jpl.v6n1p15 URL: http://dx.doi.org/10.5539/jpl.v6n1p15

\begin{abstract}
Foreign affairs have become more regulated than ever before, speaking generally about the global market economy and the interactions among states, international as well as regional organisations like the EU and ASEAN. However, how is this increased normativity, supported by the global civil society, to be theorized in relation to the two classical paradigms: realism versus idealism or liberalism? On the one hand, a new realist interpretation has been launched by Posner. On the other hand, the new cosmopolitanism of Caney envisages foreign affairs on the model of domestic affairs in so-called well-ordered countries. In this article, I argue that both positions fail to render a credible account of the increasing relevance of public international law (PIL) for inter alia politics and economics today. Yet, the functions of PIL do not match the roles of rule of law in domestic affairs.
\end{abstract}

Keywords: realism, idealism or liberalism, normativity, public international law (PIL), Kelsen, Schmitt, Posner, Teitel, spontaneous order, new cosmopolitanism, Caney, Held, IGOs, NGOs, CSOs

\section{Introduction}

One can hardly use a simplistic distinction between realism against idealism when identifying the main features of the world order today, as it has evolved after the Second World War and the fall of the Berlin Wall. The international system is no longer in a state of anarchy where the principle of self-help applies. Not only have the IGOs grown more influential than ever before, but there has also emerged a global community comprising energetic NGOs or CSOs. The key principle in public international law (PIL), viz state sovereignty, now has to somehow co-exist with other important principles, such as e.g. humanitarian intervention and national self-determination. The PIL framework has expanded bot only in terms of scope and rang of its norms but also with regard to the strength of the legitimate call for respect and enforcement.

Many changes in the world order since the end of the Second World make it imperative not to model international relations and state interactions as an international system according to Waltz model or as a society in anarchy albeit with possibilities of cooperation, following Bull's model (Burchill et al, 2009, Booth, 2011). A number of central features have been transformed, resulting in a slow growth in normativity: globalisation conducive to interdependencies in all social systems, the institutionalisation of regional blocks of states on all continents (EU, ASEAN, ECOWAS, MERCOSUR etc), increased judicialisation of politics, the creation of global courts and the growing internationalisation of national courts, judicial activism by law scholars and lawyers, the coming of a thick carpet of civil society organisations domestically and globally, the triumpf of a humanitarian philosophy over extreme ideologies, the strengthening of the international organisation like e.g the UN, etc. It is an urgent task to theorize these developments in relation to the two main theories in the discipline of international relations (IR): realism against idealism (liberalism).

\subsection{Traditional International Relations: Realism}

In the various approaches that we label "realism", normativity is merely a set of lofty principles at best and a chimera at worst. There is no public international law, because what is distinctive of a legal order is missing, namely enforcement. This entails that the rules of the international community is a mere set of recommendations, only to be employed for strategic purposes when it is not just a question of simply talking.

In realist approaches to the world order, the basic actors remain the governments of states, pursing what interests they regard to the reasons of state. The organisations active on the global scene above the states constitute coordination mechanisms whose activities have to be legitimized by the states, if and when they are taken 
seriously. The NGO:s may raise their voices, but it is the states that determine whether they are to be heard or not, let alone be allowed to influence global policy-making or implementation.

States possess a number of devices for making sure that the implications of the basic principle of sovereignty are upheld, also when growing interdependencies force states to interact continuously with each other and with IGOs or the new regional organisations above the state. Thus, states insist upon unanimity in intergovernmental bodies. And they employ the distinction between signing and ratifying a treaty as a tool to either renege upon or delay what has been agreed upon among governments. Finally, they always have the possibility to neglect to implement an agreement or a decision by an intergovernmental body.

According to realism, the mundane interests of a country - economically, geopolitically, culturally - offer sufficient guidelines for state action. The nation-state knows what it has to do to protect its so-called vital interests that may include universal or cosmopolitan principles. When a government accepts global or regional coordination with other governments, resulting in so-called regimes, then it is still a matter of promoting national interests or state reasons. Thus, entering the economic coordination mechanisms of the world - WB, IMF and the WTO - is based upon voluntary decisions that aim at capturing a part of the wealth that a global market economy can deliver for its participating players.

However much coordination among states is accomplished in IGOs and regional bodies, the states watch any threat to their existence and survival as eliciting an indisputable right to self-defence. Thus, governments may decide unilaterally upon military activities, has the right to do so, and will not refrain from going to war when attacked or seriously threatened.

It is true, realists would admit, that in the period of globalisation - starting one could say around 1980 interdependencies have increased substantially just as coordination efforts. But the logic of the international system remains the same, despite all IGOs, NGOs and the making of many new treaties. We are still living in a state of anarchy where at the end of the day the principle of self-help applies fully.

Realists look upon norms in the same manner that Platonists constructed an ideal world of perfect concepts to be opposed to the incomplete and messy world of appearances, identifying the adherents of international jurisprudence as naive idealists. Reality is made up of mundane self interests guiding the governments of states to focus upon the essence of the international situation: anarchy and self-help. Realists may recognize that the concept of reasons of state is not crystal clear, but it covers objectives entirely different from those of idealism. What, then, is normativity in international relations?

\subsection{Public International Law (PIL)}

The call for normativity in relation to the international system, modeled as anarchy and self-help, has a more solid foundation than idealist blue-prints for an international community in eternal peace, as with Kantianism for instance. It starts from the body of principles laid down in public international law (PIL), comprising not only treatises but also custom and self-evident reasons. PIL has existed for centuries, constituting the set of norms guiding diplomacy. After the Second World War, PIL has been codified in numerous standard textbooks of ever increasing size.

According to the foremost legal scholar in the 20th century adhering to the idea of normativity, PIL is based upon natural law conceptions with a pacifist orientation. Hans Kelsen (1911) could draw upon a legacy from Christian Wolff and his idea of civitas maxima when proposing his legal monism, meaning that PIL comes before national or municipal law. However, such a Christian pacifist foundation for global normativity is easy to reject.

Carl Schmitt $(1928,2002)$ disposed of this type of Christian pacifist project by denying that PIL was anything than mere recommendations, lacking the typical force of law and constituting mere wishful thinking. Thus, the Versailles Treaty had no binding force upon Germany, argued Schmitt, against the fundamental - Grundnorm idea of the idealists from Grotius and onwards that "pacta sunt servanda". Schmitt took the positivist standpoint of Hobbes, namely that there is only national law, emanating from the will of the state, i.e. legal dualism.

The Kelsen-Schmitt controversy has much dominated the theorizing on PIL, linking up this debate on the nature of PIL with the opposition between idealists and realists. PIL would be:

Morality and not law;

Recommendations that are not self-enforceable;

Norms without enforcement;

Pacifist notions that are unrealistic; 
Global regulation that would be biased or even dangerous.

One finds reminiscences of this classical antimony in the now surging debate on PIL, as it has evolved after the Great War (Besson and Tasioaulas, 2009; Dunoff and Trachtman, 2009; Klabbers, 2009; Crawford, 2012; Posner, 2009). Yet, this antimony of domestic law against morality or realism against idealism has less relevance today due to a number of recent developments.

\subsection{Evolution of PIL}

What has transformed the status of PIL is not only the increase in the number of treaties signed among the states of the world, itself pointing at efforts to come to grips of interdependencies through norm creation. Besides the quantitative change, there is a qualitative transformation of the set of norms, resulting in a higher probability of being respected and perhaps also enforced. Finally, a new set of players has emerged on the global scene, namely the NG0s operating a thick carpet of civil society orientated towards the propagation of some of the key principles of PIL. One may argue that the PIL has gotten onto a dynamism that penetrates all kinds of international interactions, powering much talked about norms into customary law, which constitutes an important part of PIL with growing relevance, like for instance the Geneva and Hague Conventions on warfare and the treatment of the victims of war.

\subsection{Scope}

It should be explicitly admitted that PIL still has to struggle with the enforcement problematic, as its norms are sometimes adhered to and sometimes not. Moreover, enforcement is in general slow and cumbersome to accomplish. Yet, PIL has so to speak penetrated state interactions in several ways:

Defining sovereignty: What is missing in the realist theories is one of the most fundamental facts about international games, i.e. the concept of the state is legally specified in PIL with implications for e.g. the high seas etc.

Somewhat contradictory, realists admit that state sovereignty is no longer the same, when things and matters of concern are compared today with - say - the 1930s. Real state sovereignty has shrunk, according to some considerably (Krasner, 1999). But at the same time they claim that it remains the solid foundation of the international system (Bickerton, Cunliffe \& Gourevitch, 2005). However, realists fail to acknowledge that the concept of state sovereignty is much a legal conception. And it is fully specified in the first part of the PIL with both a most general definition and a most detailed specification of the rights and duties entailed in this legal conception.

Governments would not be able to act on behalf of the state, if they did not follow the norms of PIL concerning the state - its attributes and its rights and duties as well as liabilities. In reality, governments tend to follow these norms in detail with a high precision, as they wish to avoid any criticism from other governments or civil society. When governments collide or are engaged in a row, the discourse immediately becomes legalistic when arguments taken from the arsenal of PIL.

Protecting humanity: Most of the dynamic developments in PIL recently refer to norms that protect not the states but humanity, meaning single persons. Besides the strengthening of the set of rules about human rights, moving more and more towards group rights and compensation justice, there are the normative innovations about humanitarian intervention and protection against criminal injustices committed by rulers against individual citizens.

The PIL is not a coherent set of norms. One may divide the bulk of its rules into either state preserving, focused upon non-intervention and its entailments, on the one hand and protection of persons on the other hand, especially his/her so-called habeas corpus rights.

Attempting both 1) and 2) makes PIL sometimes contradictory in its normative implications. Thus, foreign governments may acknowledge groups in uproar as the legitimate representatives of a country, although the government in power may refer to the rule of non-intervention in its internal affairs.

Endorsing regionalism: A major change in PIL is the making of numerous treaties about regional cooperation or integration. These treaties and norms introduced by means of them add considerably to normativity in the present world order.

The creation of some ten regional blocks of states has been conducive to state cooperation, both within these blocks and among the blocks. It is often stated that economic coordination, starting from the FTA and going towards the Single Market and Monnaie Unique, has been the chief motivation. However, one finds many examples of regional coordination mechanisms set up for security reasons or even culture. Clearly, regional 
norms about peaceful interaction, free trade and cultural exchanges limit the scope for governments to pursue so-called state reasons.

\subsection{Range}

No country can hope to place itself outside of PIL. This system of norms apply also to states that are not members of the IGO:s, like for instance the UN framework. When a government applies for membership in the IGOs or the regional groups of states, then it assumes responsibility for respecting and implementing the rules of these organizations. However, voluntary entrance into these global or regional organizations does not limit the range of application of many of these norms.

The WB, the IMF and the WTO have each of them reached a most comprehensive coverage, based upon voluntary membership. And all three have at their disposal various means for bringing states to respect their frameworks of rules.

Although regional groups of states differ much in terms of compactness, few countries stand outside the now evolving system of regional organizations above the states of the world. It is a matter of so-called rogue states or states in anarchy or anomie. Some regional groups of states have expressed integration ambitions that remind of the EU project, but it remains to be seen what they can accomplish, given that they would probably not be able to marshal the resources that the EU seems to be willing to gather - take for instance UNASUR, ECOWAS, SADC and perhaps also the ASEAN.

\subsection{Force}

The stylized objection to the PIL framework of a fundamental deficiency, when looked upon from the point of view of law, namely its weakness in terms of implementation or enforcement, appears less pertinent today. It seems undeniable that the respect for PIL has grown considerable over the last decades. One may wish to distinguish between the following aspects of the implementation of PIL:

Day-to-day observance of many of the rules of PIL;

Slow but steady enforcement of a few of the rules of PIL through the global system of courts;

Protests and moral indignation over the breaking of some of the rules of PIL.

When scholars claim that the PIL merely constitutes a set of recommendations and lofty moral ideas, they tend to entirely bypass the regular observance of many rules in the PIL: diplomacy, the High Seas, global trade and foreign direct investment, international banking regulations, Antarctica and the North Pole, Ozone, etc. And they tend to downplay the importance of the activities of the ad hoc courts, operating extremely slowly, as well as those of the World Court, often only stating advisory opinions, and the International Criminal Court, seemingly incapable to having some of its perpetrators handed over to The Hague. What these scholars cannot deny, however, is the speedy reaction to and often condemnation of violations of the PIL by outside governments, the world media and the NGOs and CSOs. The call for transitional justice may have consequences in several countries (Skaar, 2012).

\subsection{Rectification and Compensation}

Emphasizing the distinction between idealism and normativity, one may argue that global economic justice is unfeasible, but it does not reduce the chances for those unjustifiably hurt or damaged to get justice. As a matter of fact, the probability of a successful claim for either rectification or compensation has increased sharply as a result of judicial activism in the last decades. Consider the fate of the so-called historical minorities: the Australian Aborigines, the North American Indians and the Eskimos, the Pacific Islanders, the Maoris, etc.

It is true that what has been accomplished in terms of correction of historical injustices falls short of what is claimed not only by the so-called peoples with history but also in general by minorities in many countries. Yet, the process of globalization has strengthened the legitimacy of a key norm in PIL: self-determination.

When the idea of global economic justice is formulated in an abstract manner (Pogge, 2002), then it is a matter of idealist philosophy that is very difficult to translate into workable policies that are incentive compatible. However, normativity in the form of compensation for specific historical injustices can be handled in a satisfactory manner by the courts or through governmental activity.

\subsection{The Stakeholders}

The NGOs have presented themselves as the adherents of PIL, seeking not only to increase the respect for its norms but also to augment both its scope and range. The new complex notion of global accountability that the NGOs pursue may be unpacked into four components, viz transparency, consultation, evaluation and correction. 
Can the NGOs promote global democracy? Not underestimating their new role in the global village, one must ne aware of their limitations (Scholte, 2011).

First, the NGOs or civil society organisations (CSO) link up with the key governance institutions in very different ways. In some of these global mechanisms the CSO:s are much integrated into the decision-making processes, whereas in others they have been rendered marginal roles. In one of them, the Global Fund, the CSO:s are part of the formal organisation. The UN provides more opportunities for accountability by CSO:s than the three sisters: WB, IMF and WTO. Second, in the highly technically orientated ICANN, the CSO:s fail to find an active role, which is the exact opposite in the very politically relevant WFTO. Finally, accountability lends itself better to the achievement of transparency and evaluation than to influence and changes. More of accountability does not automatically translate into policy improvements or equal influence for all CSO:s, accountability for CSO:s not effectively promoting the influence or position of the poor countries of the world. Yet, there are certain restrictions upon the feasible contribution of CSO:s, whether from the North or the South, to the accomplishment of global democracy.

One may perhaps wish to emphasize the following features of the COSs: fundamental intergovernmental nature of several of the governance bodies - the IGOs - they appraoch, the problematic question of the self-accountability of many CSO:s, the need to employ formal organisation in order to integrate the CSO:s into stable and predictable decision process. All this implies a risk for bureaucratisation, and the favoured access for CSO:s representing business and finance.

\subsection{Transformation of International Interactions}

One major factor in promoting normativity is the speed with which new information flows around the globe today. This is reflected in the constant updating of information in the many news channels: CNN, BBC, Al Jazeera, Fox, France 24, etc. These media constitute only one expression of the global communication village, as also governments have poured lots of resources into various ways to achieve constant updating.

More information, better accuracy and quick updating have the following consequences for the monitoring of PIL:

Presumed violations of basic rules are when known communicated worldwide;

Perpetrators offending the rules of PIL cannot expect to go undetected for a long time;

Clear violations of PIL will be recorded almost at once and transmitted worldwide, meaning that there is memory of what has taken place;

Offences against the rules of PIL can be monitored for weeks and stored in detail in order to allow for future examination and possible court procedures.

As information as well as the continuous updating of data is crucial for monitoring of evens, normativity is much enhanced by the immense technological advances in communication recently. What the protagonists of normativity have at their disposal is nothing less than a set of tools for constant and detailed surveillance of the observance or violation of PIL.

\section{Resurgency of Naked Realism}

One could perhaps surmise that the path towards more of regulation of global and regional affairs and interactions has been accompanied by a reduction in the relevance of the realist framework of analysis. Noticeable are the attempts to revise naked realism of Morgenthau type into regime theory or rational choice institutionalism that partly acknowledges normativity (Krasner, 1983, Young, 1989, Keohane, 2005). Yet, hard core realism is still alive, as several scholars maintain that states are the key players and they are driven by self-interested incentives.

\subsection{Future of Geopolitics: Realistic?}

One may contrast the perspective outlined here of growing normative in the international community with a much debated geopolitical analysis of future scenarios. The following predictions/possibilities/opportunities (whichever one may choose) are portrayed (Friedman, 2011):

The break-up of Russia through invasion from both the West and East;

The expansion of Turkey in various directions;

The collision between the US and Mexico concerning the former Mexican territories, lost in 1845-1848. 
All these projected changes would come up against PIL. Does it entail that they are little likely to take place? I would be inclined to argue thus. The PIL framework makes such huge scale geopolitical changes improbable, because they would involve - massively - the breaking of the basic principle: "Pacta Sunt Servanda". Can one really spell out the implications of state self-interests without taking into account the attitudes of foreign policy-makers towards international law (Alden and Aran, 2012)?

Interestingly, Freedman's geopolitics targets the largest state in the world, territorially speaking. He evidently sees no hinder for its neighbours to cut it up: Finland regaining Karelia, the EU capturing huge parts of areas controlled once in historical times, Turkey moving into the Caucasus and in the East both China and Japan taking a bulk of Siberia. This is complete nonsense. All EU member states are bound by the "normative power Europe", which entails a firm commitment to peace and respect for territorial integrity. Turkey will face internal challenges to deal with, like the Kurdish question and the shaky balance of power in the Middle East. Finally, the price for China or Japan taking on nuclear Russia could be extremely high, especially if other powers in the Pacific decide to support Russia.

One may of course question whether it would be a state interest for the EU member countries to try once again the impossible task of defeating the Russian bear - an enterprise attempted trice the last three centuries (Charles XII, Napoleon and Hitler) with always the same outcome, i.e. crushing defeat. The notion of real or rational state self-interests in realism turns highly problematic, when a state engages in aggressive warfare, which could equally well be explained by misconceived leader preferences and false beliefs. But Goldsmith and Posner (2005) do not hesitate to build a whole theory about PIL on the assumption that these motives or reasons can be specified objectively.

\subsection{PIL as Convenient Recommendations}

The rebuttal of normativity with PIL from Goldsmith and Posner is entirely different from naive geopolitics. They present a most elaborate theory of PIL, combining jurisprudence with international relations, interpreted with a few basic game theory models.

Eric Posner (2009) is highly sceptical about Voelkerrecht, its foundations and its claim to normativity, meaning that its key principles bind sovereign states. However, Goldsmith and Posner (2005) do not reiterate Schmidt's position towards PIL. They confirm that PIL is LAW, and not merely the morals of victorious governments (Goldsmith and Posner, 2005: 3 and 225-26). Yet, they completely deny normativity. Yet, how could a system of norms that constitute LAW lack entirely normativity?

According to this theory of PIL, PIL is often complied with but not because of any binding force of its norms. Compliance can be best explained by the operation of state self interests and their coordination in the games that are played out underneath PIL. Moreover, governments have no obligation whatsoever to comply with PIL. Thus, the enforcement is entirely up to the states in the international system that may or may not comply alternative may or may not retaliate against reneging by other governments, all based upon consideration of self-interests.

Posner's rejection of any obligation with PIL may appear somewhat drastic, but it may be related to the perennial debate about what is law (Raz, 2009). Law, all agree, is a huge ordered set of couples of norms and their enforcement (compliance, punishment):

Law $=<$ norms, enforcements $>$.

What is contested is whether the binding nature (validity) of the first element - norms - is the same or different from the efficacious nature of the second element - compliance or punishment. Kelsen's legal positivism took the view that law's validity is conditioned by its effective enforcement, whereas Swedish philosopher Axel Hägerström developed the legal realist approach claiming that legitimacy of norms is nothing but the same as their probability of compliance. Legal pragmatists like for instance Richard A. Posner (2001:20-21) shares the Hägerström view: "law is a prediction about what the judges will do when confronted with a specific set of facts". Since states sometimes comply and sometimes renege with PIL on the basis of self-interests, Posner draws the conclusion that PIL has no normativity or binding validity (“opinio juris”) at all, neither Treaty Law nor Customary Law.

It is true that PIL differs from domestic law as far as the probability of compliance or enforcement is concerned, at least in well-ordered countries. But this was always the standard objection towards PIL. And how can it lead so far that it is claimed that it has no binding force whatsoever, at the same time as the probability of enforcement is increasing? PIL may be deficient as LAW, but how can it be LAW and have no normativity? 
PIL is grounded only upon state self-interests, guiding them to various forms of coordination at best, as well as to renege at worst. States would have behaved in the same way without treaties or customary international law, in accordance with various equilibria in non-cooperative game theory. This position bypasses entirely the transaction cost saving nature of LAW. States could not handle all the transaction costs from solving a myriad of alternative interaction games on the basis of self interests, day in and day out in a set of diverse situations. Better to rely upon the binding nature of valid norms with a general scope, guiding action in similar circumstances.

\section{Resurgence of Idealism as New Cosmopolitanism}

One may contrast the new realist argument by Posner with the new cosmopolitanism, which dreams of a development of PIL towards morals and natural law. However, the new cosmopolitanism has little relevance for PIL, as it is utopian.

\subsection{PIL = Global Rule of Law?}

Ruti G. Teitel suggests that PIL has evolved so much recently that it can be considered as a global rule of law regime, comparable to the Rechtsstaat within a country. Her argument consists of three parts theorizing what she calls humanity's law (Teitel, 2011):

Humanity's law comprises essentially the following parts of the PIL: the Geneva and Hague conventions about the conduct of inter-state war: just war as well as justice in war, the Treaty of ICC (International Criminal Court) and the Security Council decisions concerning the ad hoc courts for Former Yugoslavia and Rwanda: personal security in intra-state civil war and anarchy;

Humanity's law offers person protection in several ways similar to rule of law regimes within a country;

Humanity's law has a structure similar to that of domestic rule of law.

I would not hesitate to suggest that the suggested strong linking of the PIL with cosmopolitan moralism would weaken the emerging normativity in international relations. What Teitel calls "humanity's law" is hardly comparable to rule of law in so-called well-ordered societies.

Firstly, the Geneva Conventions are hardly new, as they began to be laid down around 1900. Second, together with the Hague Conventions they offer a number of norms about the conduct of war and use of violence in conflicts, but these norms have had almost nil impact upon reality. Whereas the so-called efficiency of rule of law tends to be high in the capitalist democracies or well-ordered countries, the opposite is true of humanity's law. In addition, the ICC has not met with universal acceptance and the capacity of the ad hoc tribunals to punish perpetrators has been rather meager. Thus, also with regard to legitimacy the framework of humanity's law is hardly to be compared with the rule of law regime when solidly implemented as within the OECD countries. Thirdly, whereas humanity's law targets the protection of civilians against physical violence from either interstate or intrastate conflicts, the rule of law regime has a much broader scope than merely the Habeas Corpus rights. Thus, rule of law today entails constitutionalism, which is lacking in humanity's law.

Rule of law only exists when there is a high probability that its norms are complied with, either directly or indirectly through enforcement against deviations from observing these rules. Teitel speaks of humanity's law as "providing protection", or as "offering protection" etc. But the respect for these norms is often so low that this is only a manner of talking about LAW.

When theorizing globalization, cosmopolitanism and law, one cannot bypass the insights from the philosophy of law, distinguishing between norms on the one hand (validity) and their implementation on the other hand (efficacy). Just because the new cosmopolitanism speaks much about universal rights, it does not turn these moral rights into substantive law.

\subsection{PIL = New Cosmopolitanism?}

The new theory of cosmopolitanism, launched by so-called liberal egalitarians, purports to be a global political theory for the globalisation age. It is based upon various theories of justice in political philosophy and results in some stunning or utopian conclusions. A key text is that of Caney (2006), who comes to the following results, which are not at all in agreement with PIL:

- People in Kuwait are not entitled to its oil reserves:

- People should be taxed for using the resources in their territory, and the proceeds spent on improving the poor throughout the world:

- There should be a system of multi-level government in which the power is removed from states to both supra-state and sub-state authorities. 
New cosmopolitanism is much broader than old cosmopolitanism according to the Kantian framework. Whereas the latter concentrated upon peace and the regulation of violent conflicts, new cosmopolitanism underlines global distributive justice besides launching civil and political rights. It goes far beyond public international law. Are we then to say that it gives directions for the future improvements of the law of the international community "Voelkerrecht"? I doubt that, as the new cosmopolitanism with for instance the three proposals above is utopian, whereas the PIL framework is practical.

The call for global democracy is a cornerstone in the new cosmopolitanism (Held, 1995). Scholars calling for more of democracy envisage either small reforms of global institutions in an egalitarian direction or they suggest that pressure should be exercised upon countries that are illiberal. PIL endorses state sovereignty together with non-interference on the one hand as well as human rights as well as humanitarian intervention on the other hand. Thus, PIL as a whole is hardly a consistent normative framework. But it holds true that in any case PIL does not entail global democracy, which call today would amount to a culture blind "exigency" (Rawls, 2001).

The augmentation of normativity along with the process of globalisation has led to a debate about the pros and cons of global constitutionalism (Krisch, 2011; Dobner and Loughlin, 2012). However, one should separate between the expansion of PIL on the one hand and various efforts at regional or global constitutionalism on the other hand. As the failure of EU constitutionalism shows, constitutions make much sense at the level of nation-states. Globally, the PIL framework advances slowly but inexorably by means of the principle of "muddling through".

\section{Conclusion}

In the philosophy of right and legal theory, it is emphasized that ethics and justice have to do with rules, whether the approach is a deontological or one of consequentiality. Legal norms fulfill this requirement of generalisability or universalisability, inheret in morality (Hare, 1972). In various domains of activity economics, environment, state interactions, humanitarian efforts, there has occurred a seminal trend towards normativity since 1945 and especially 1990. It blurs the traditional and sharp separation between realism and idealism that has dominated IR.

The drive towards more of normativity has accompanied the major changes in the international system or foreign relations:

The strengthening of the IGOs;

The creation of regional organizations;

The evolution of a global civil society: NGOs and CSOs;

The creation of new global courts, ad hoc or permanent besides the ICJ;

The expansion of domestic courts into international affairs;

The emergence of multinational or transnational companies with a dominant position in trade and foreign direct investment.

However, growing normativity does not entail global constitutionalism or even that the basic problem of public international law - implementation or enforcement - has been resolved adequately. Idealism, especially in the form of utopian cosmopolitanism remains unrealistic, but realism has been tempered by normativity.

The PIL is not planned or designed as a whole set of rules. Instead, it has expanded in scope and range in an incremental fashion. It builds upon the accumulated wisdom of a variety of efforts over a few centuries to codify a set of reasonable rules for the interaction of states as well as the protection of persons - a spontaneous order (Hayek). It still runs with an implementation deficit, as enforcement is often lacking. It is weak in the field of global environmental protection. Yet, global constitutionalism is as utopian or questionable as the idea of world government. Constitutionalism works best at the state level. One may be sceptical about the pros of attempting to create constitutions for regional organizations.

\section{References}

Alden, C., \& Aran, A. (2012). Foreign Policy Analysis: New Approaches. London: Routledge.

Besson, S., \& Tasioulas, J. (2009). The Philosophy of International Law. Oxford: Oxford U. P.

Bickerton, C., Cunliffe, P., \& Gourevitch, A. (2006). Politics without Sovereignty: A Critique of Contemporary International Relations. London: Routledge.

Booth, K. (2011). Realism and World Politics. London: Routledge. 
Burchill, S., Linklater, E., Devetak, R., Donnelly, J., Nardin, T., Paterson, M., Reus-Smit, C., \& True, J. (2009). Theories of International Relations. London: Routledge.

Caney, S. (2006). Justice Beyond Borders. A Global Political Theory. Oxford: Oxford U. P.

Crawford, J., \& Koskenniemi, M. (2012). The Cambridge Companion to International Law. Cambridge: Cambridge University Press.

Dobner, P., \& Loughlin, M. (2012). The Twilight of Constitutionalism? Oxford: Oxford University Press

Dunoff, J. L., \& Trachtman, J. P. (2009). Ruling the World? Constitutionalism, International Law, and Global Governance. Cambridge: Cambridge University Press.

Friedman, G. (2011). The Next 100 Years. New York: Doubleday.

Goldsmith, J. L., \& Posner, E. A. (1995). The Limits of International Law. Oxford: Oxford U. P.

Hare, R. (1972). Essays on the Moral Concepts. Oxford: Clarendon Press.

Held, D. (1995). Democracy and the Global Order: From the Modern State to Cosmopolitan Governance. Stanford: Stanford U. P.

Hägerström, A. (1953). Inquiries into the Nature of Morals and Law. Stockholm: Almqvist \& Wicksell.

Kelsen, H. (1911). Hauptprobleme der Staatrechtslehre. Tübingen: Mohr.

Krisch, N. (2011). Beyond Constitutionalism: The Pluralist Structure of Postnational Law.

Klabbers, J., Peters, A., \& Ulfstein, G. (2011). The Constitutionalization of International Law. Oxford: Oxford U. P. http://dx.doi.org/10.1163/157237411X642908

Keohane, R. (2005). After Hegemony. Princeton: Princeton U. P.

Krasner, S. D. (1983). International Regimes. Ithaca: Cornell U. P.

Krasner, S. D. (1999). Sovereignty: Organized Hypocrisy. Princeton: Princeton U. P.

Manners, I. (2002). Normative Power Europe: A Contradiction in Terms? Journal of Common Market Studies, 40(2), 235-258. http://dx.doi.org/10.1111/1468-5965.00353

Pogge, T. (2002). Global Justice. Oxford: Wiley-Blackwell.

Posner, E. A. (2009). The Perils of Global Legalism. Chicago: University of Chicago Press.

Posner, R. A. (2001). The Problems of Jurisprudence. Cambridge, MASS: Harvard U. P.

Rawls, J. (2001). The Law of Peoples. Cambridge, MASS: Harvard U. P.

Raz, J. (2009). The Authority of Law: Essays on Law and Morality. Oxford: Oxford U. P.

Schmitt, C. (1928, 2002). Verfassungslehre. Berlin, Dunker and Humblot.

Scholte, J. A. (2011). Building Global Democracy. Cambridge U. P.

Skaar, E. (2012). Does Transitional Justice Promote Reconciliation? Transitional Justice Review, 1(1), 54-103

Teitel, R. G. (2011). Humanity's Law. Oxford: Oxford U. P. http://dx.doi.org/10.1093/acprof:oso/9780195370911.001.0001

Young, O. (1989). International Cooperation. Ithaca: Cornell U. P. 